\title{
Trend Analyses of Parameters of Equations for Maximum Energy Consumption Ratio Achievable in Ubicomp MANETs Using Location-Aware Transmission.
}

\author{
M. Kaleem GALAMALI, Assoc. Prof Nawaz MOHAMUDALLY
}

\begin{abstract}
Location-tracking, ubicomp functionalities and MANET transmission strategies are subject to quite promising research [36-72]. It still remains a fact that the area of modelling in ubicomp to assess predictability features is at its beginning stages. The sub-field of energy management is especially important since in present technology level, battery power is still considered constrained. Previously, a research was carried out to quantify and model the maximum ratio of energy consumption (Max_R) recordable for a CBR gauged against the energy consumed by the sender, for node densities of 7 until 56. The corresponding model was observed to be linear previous to the peak value and decreasing exponential as from the peak value onwards.
\end{abstract}

In this paper, the next milestone of probing is put forward as: "What are the trends of variation observable within each parameter of the equations of curves obtained for metric Max_R [20] over varying node densities?"

Studying the behaviour of components of applicable models for metric Max_R and accordingly model the behaviour of each component mathematically is of paramount importance since it will involve tremendous efforts and discord resolution among various researchers. The outcome put forward will assist designers towards better understanding of ubicomp and provision hardware and algorithmic tactics into ubicomp architecture for enhanced energy management. This paper is a follow-up of previous research [1-35].

Key terms: Ubicomp- Ubiquitous Computing, MAUCMobile and Ubiquitous Computing, MANET- Mobile Adhoc Network, CBR- Constant Bit Rate, ECR- Energy Consumption Ratio, Max_R- Maximum Ratio.

M. Kaleem GALAMALI,

University of Technology Mauritius (student) Mauritius

Assoc. Prof Nawaz Mohamudally University of Technology Mauritius, Mauritius

\section{Introduction}

MANETs remain a promising solution to unplentiful resource availability in ubicomp. In MANETs, energy consumption load is distributed among all nodes present in the topography. The method of distribution remains ponderously influenced by node density. A former study [20] was endeavoured towards finding the trends observable for metric Max_R for node densities ranging from 7 until 56. The model suggested in that paper [20] was split into three:

- For node numbers 7 until 25, the exponential model has been observed of form:

$G(x)=a * \exp (b *(x-1.0))+c$

- For node numbers 26 onwards, previous to the peak value observed, the tendency is linear of form:

$F(x)=d * x+f$

- For node numbers 26 onwards, as from the peak value onwards, the tendency is exponential of form: $G(x)=a * \exp (b *(x-2.0))+c$

Here, the equations of the model have involved 6 parameters: a, b, c, d, f and $\mathrm{k}$. The next analysis required for metric Max_R is the formulation of model equations for the parameters of the equations mentioned above.

The key contributions of this paper is the settling of the trend of variation for each parameter of the equations involved in the model for metric Max_R presented in former paper [20] whose tables 1(a) and 1(b) are reutilised here. The mathematical methods derived here may possibly be programmed into software simulators and provide an additional utility for designers to better understand the evolution and predictability of ubicomp characteristics to assist in equipping future ubicomp architecture. The rest of this paper is organised as follows: section 2- Parameter Trend Analysis- Metric Max_R, section 3- Conclusion and References.

\section{Parameter Trend Analysis - Metric ECR. \\ 2.0 General Procedure Adopted.}

The tabulated data for each parameter of equations of model for Max_R is plotted on gnuplot. Graphical analyses are conducted and general observations are reported and various equations of fit are tried. Choice of best fit was made firstly based on chi-square value. Secondly, for parameters $\mathrm{b}, \mathrm{d}$ and $\mathrm{f}$ most likely extendability at node numbers 80 and 100 is sought; for parameter 'a', extendability at node numbers 100 and 
150 is considered. Finally, the values of parameters for each Max_R parameter of equation is noted.

\subsection{Trend Analysis - Max_R parameter " $a$ ".}

The curve obtained shows a decreasing trend with decreasing rate of decrease.

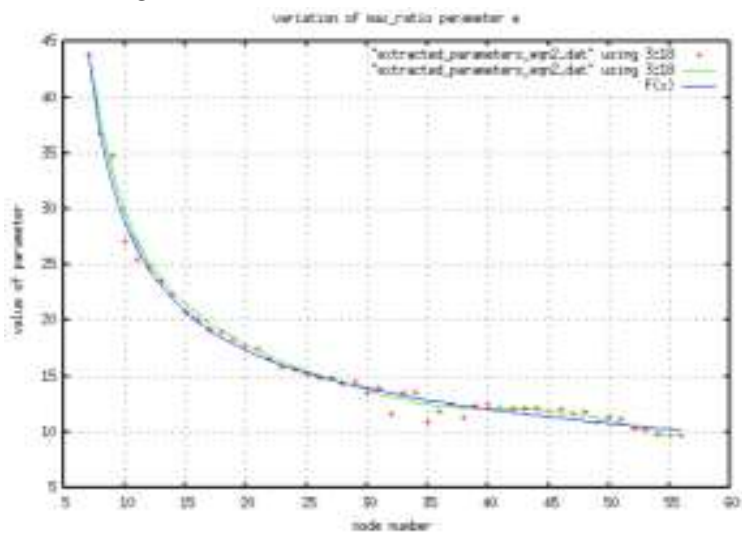

Figure 1: Max_R parameter a

The potentially applicable equations are:

$$
\begin{array}{cc}
\text { 1. } F(x)=\left(a * x^{2}+f\right) /(\exp & ((b * x)+c)+d) \\
\text { Ch_sq }=0.677346 & F(100)=4 . \ldots \ldots \\
F(150)=1.19 \ldots \ldots & \\
\text { 2. } F(x)=(a * x+f) /(\exp & ((b * x)+c)+d) \\
\text { Ch_sq }=0.613511 & F(100)=7.047411235 \\
F(150)=4.817554527 &
\end{array}
$$

\section{Choice of best fit for Max_R parameter a}

The equation in part 2 above has been selected because of smallest ch_sq and good extendability. The parameters obtained for best fit are:

$\mathrm{a}=0.386479, \mathrm{~b}=0.0112776, \mathrm{c}=1.05997, \mathrm{~d}=$ $2.99143, \mathrm{f}=3.09767$

\subsection{Trend Analysis - Max_R parameter " $b$ ".}

Generally the curve depicts an increasing tendency with decreasing rate until about node number 20 , after which (mostly) a straight line with a small positive gradient is observed.

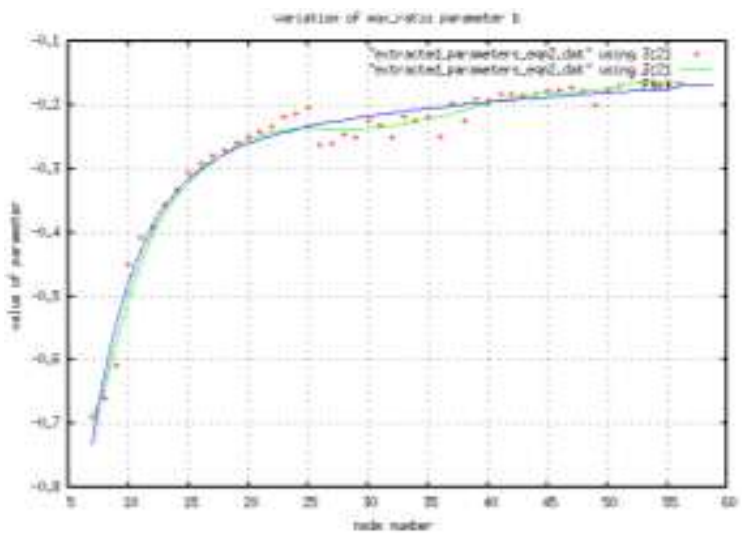

Figure 2: Max_R parameter b
The equation of best fit is:

$$
\begin{aligned}
& \mathrm{F}(\mathrm{x})=\mathrm{a} * \exp \left(\mathrm{b}{ }^{\star} \mathrm{x}\right)+\mathrm{C}^{*} \mathrm{x}^{\mathrm{d}} \\
& \text { Ch_sq }=0.000500 \quad \mathrm{~F}(80)=-0.1521185515 \\
& \mathrm{~F}(100)=-0.1403353
\end{aligned}
$$

The parameters obtained for best fit are:

$\mathrm{a}=-2.65535, \mathrm{~b}=-0.283551, \mathrm{c}=-0.74097$, $\mathrm{d}=-0.361317$

\subsection{Trend Analysis - Max_R parameter " $C$ ".}

The curve depicts a damped oscillation.

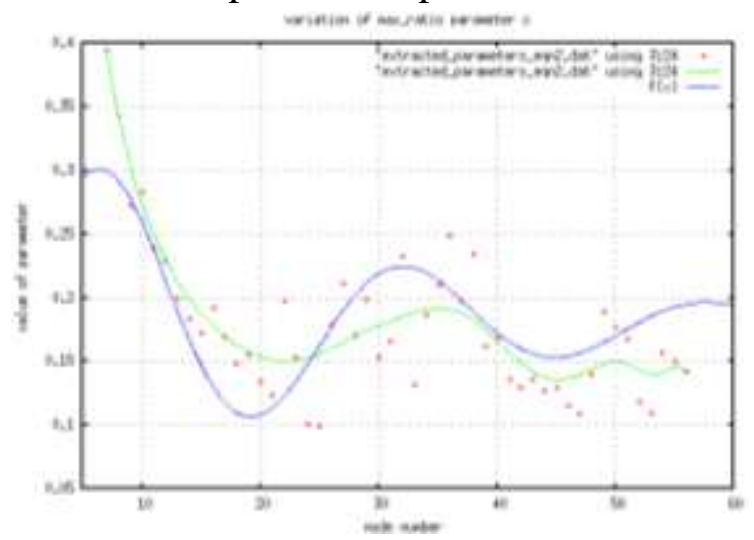

Figure 3: Max_R parameter c

The problem faced in this particular situation is that the "fit" command in gnuplot conflicts with an internal file. The manual attempt has however been quite convincing. The result remains open for further refinement here.

$\mathrm{F}(\mathrm{x})=\mathrm{a} * \exp (-\mathrm{b} *(\mathrm{x}-7)) * \cos$
$(2 * \mathrm{pi} *(\mathrm{x}-7) * \mathrm{~b})+\mathrm{c}$ The parameters obtained for best fit are: $\quad \mathrm{a}=0.12$, $\mathrm{b}=0.039, \mathrm{c}=0.18$

\subsection{Trend Analysis - Max R parameter " $d$ ".}

The curve obtained from a very sparse plotting, depicts a very slight decreasing linear trend.

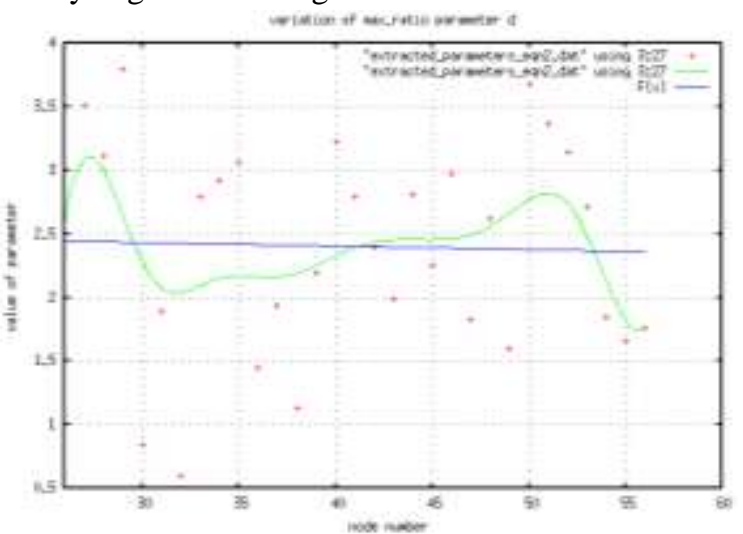

Figure 4: Max_R parameter d

The equation of best fit is:

$$
\begin{aligned}
F(x)=d^{*} x+f & \\
\text { Ch_sq } & =0.701358 \\
F(100) & =2.237912
\end{aligned}
$$


The parameters obtained for best fit are: $\quad d=-0.002$ $78572, \mathrm{f}=2.51648$

\subsection{Trend Analysis - Max_R parameter " $f$ ".}

The curve obtained shows a decreasing trend. The rate of decrease also decreases with increasing node number.

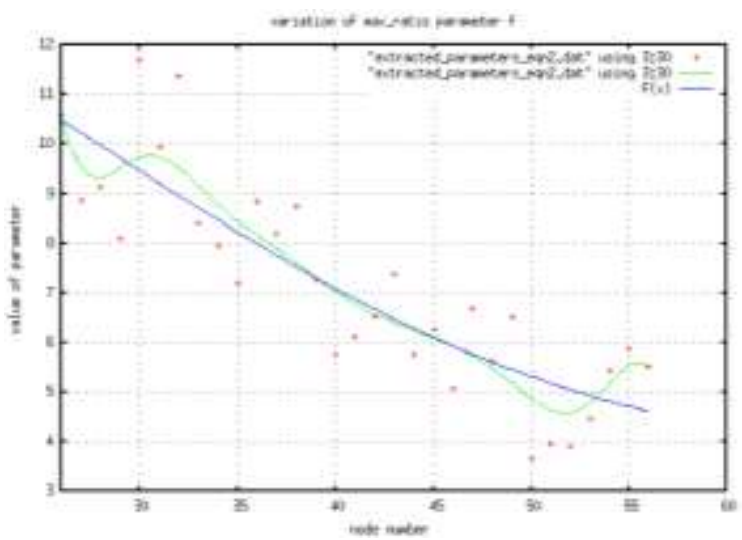

Figure 5: Max_R parameter f

Potentially applicable equations of trend are

1. $F(x)=d * x+f$

$$
\begin{aligned}
& \text { Ch_sq }=1.27766 \quad \mathrm{~F}(80)=-0.647 \ldots \\
& \mathrm{F}(100)=-4.63 \ldots \ldots \ldots
\end{aligned}
$$

2. $F(x)=a * \exp (b * x)+c$ Ch_sq $=1.27668$

3. $\quad F(x)=a * \exp \left(b * x^{2}\right)+c$ Ch_sq $=1.24809$

4. $F(x)=a * \exp \left(b * x^{2}\right)+(c * x)$ Ch_sq $=1.24165$ $\mathrm{F}(80)=3.9873$ $\mathrm{F}(100)=4.68 \ldots \ldots$

5. $F(x)=a * \exp \left(b * x^{2}\right)+(c * x)+d$ Ch_sq $=1.23983$

Curve increases seriously after some time, i.e. not good for projection.

\section{Choice of best fit for Max_R parameter $\mathbf{f}$}

The equation in part 4 above has been selected because of better extendability even if ch_sq is not smallest. Parameters for best fit are:

$\mathrm{a}=14.1194, \mathrm{~b}=-0.00062213, \mathrm{c}=0.0465492$.

\subsection{Trend Analysis - Max_R parameter " $k$ ".}

Parameter $\mathrm{k}$ is the integer value from where $\mathrm{G}(\mathrm{x})$ starts. The curve obtained depicts mostly a staircase diagram with increasing tendency. This is so because value of $\mathrm{k}$ is measured to nearest integer and hence accuracy requirements for trend observation is not fully appropriate. The solution adopted here is to derive value of $\mathrm{k}$ obtained from equation and round it off before being used.

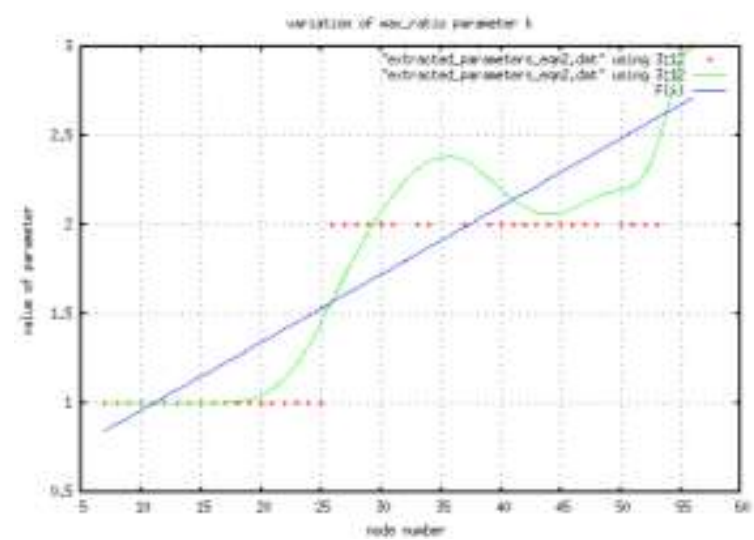

Figure 6: Max_R parameter $k$

The equation of best fit is:

$$
\begin{aligned}
F(x)= & d * x+f \\
\text { Ch_sq } & =0.195944
\end{aligned}
$$

The parameters obtained for best fit are: $\quad \mathrm{d}=0.038$ $1753, \mathrm{f}=0.577479$

\section{Conclusion.}

This piece of probing was intended to and has developed the applicable models of trends of the parameters of equations for the metric Max_R in a MANET topography of $300 \times 300 \mathrm{~m}^{2}$. The models have been founded with quite complex mathematical equations. These will certainly support in studying MANETs for MAUC environment from a software engineering notion, together with formulating computational algorithms to be incorporated into simulators for appropriate studies of MANET. This experiment was run in NS-2 over linux. The plottings and "fit" attempts were practised in gnuplot. Criteria used for evaluating best fit stay the smallest reduced chi-square values and most recommendable extendability of equations obtained.

Assumptions stated in previous paper [20] are carried forward in this paper also. Correctness of gnuplot and its accuracy features are assumed as good, even if it generated a conflict for Max_R parameter 'c'. Solving this problem over more sophisticated mathematical software is desirable.

Further work identified remain: formulating methods of predictability for metric Max_R and its trend and reporting observations of certain critical values identified.

\section{References}

[1] M. Kaleem GALAMALI, Assoc. Prof Nawaz MOHAMUDALLY, Towards Dependable Pervasive Systems-A Position and Vision Paper, CEET 2014

[2] M. Kaleem GALAMALI, Assoc. Prof Nawaz 
MOHAMUDALLY, Model of Energy Savings achievable with Location-aware Node-to-Node Transmission in UbiComp , CEET 2014

[3] M. Kaleem GALAMALI, Assoc. Prof Nawaz MOHAMUDALLY, Model of Energy Savings achievable with Location-aware Node-to-Node Transmission in UbiComp Using Location Refresh Intervals, CEET 2014

[4] M. Kaleem GALAMALI, Assoc. Prof Nawaz MOHAMUDALLY, Model of Energy Savings achievable with Location-aware Transmission in UbiComp Using Relays, CEET 2014

[5] M. Kaleem GALAMALI, Assoc. Prof Nawaz MOHAMUDALLY, Mathematical modeling of need of exact number of relays to ensure seamless mobility in mobile computing, CEET 2014

[6] M. Kaleem GALAMALI, Assoc. Prof Nawaz MOHAMUDALLY, Modelling of need for multiple relays for ensuring seamless mobility, CEET 2014

[7] M. Kaleem GALAMALI, Assoc. Prof Nawaz MOHAMUDALLY, Investigation of prominence of placements of relays in a ubicomp topography,

[8] M. Kaleem GALAMALI, Assoc. Prof Nawaz MOHAMUDALLY, Model of energy savings achievable with location-aware transmission in ubicomp using optimised number of relays.

[9] M. Kaleem GALAMALI, Assoc. Prof Nawaz MOHAMUDALLY, Investigation of Prominence of Placements of Optimised Number of Relays in a Ubicomp Topography using Location-Aware Transmission, CEET 2015

[10] M. Kaleem GALAMALI, Assoc. Prof Nawaz MOHAMUDALLY, Extending Node Battery Availability in Ubicomp with Location-Aware Transmission, CEET 2015.

[11] M. Kaleem GALAMALI, Assoc. Prof Nawaz MOHAMUDALLY, Extending Node Battery Availability in Ubicomp with Location-Aware Transmission using Location Refresh Intervals, CEET 2015.

[12] M. Kaleem GALAMALI, Assoc. Prof Nawaz MOHAMUDALLY, Extending Node Battery Availability in Ubicomp with Location-Aware Transmission using Uniformly Placed Relays, CEET 2015.

[13] M. Kaleem GALAMALI, Assoc. Prof Nawaz MOHAMUDALLY, Extending Node Battery Availability in Ubicomp with Location-Aware Transmission Using Optimally Placed Relays, CEET 2015.

[14] M. Kaleem GALAMALI, Assoc. Prof Nawaz MOHAMUDALLY, Model of Sender Node Energy Savings Achievable with Location-Aware MANET Transmission in Ubicomp. ACCN 2016

[15] M. Kaleem GALAMALI, Assoc. Prof Nawaz MOHAMUDALLY, Model of Overall Node Energy Savings Achievable with Location-Aware MANET Transmission in Ubicomp. ACCN 2016

[16] M. Kaleem GALAMALI, Assoc. Prof Nawaz MOHAMUDALLY, Model of Sender Node Extra Energy Savings Achievable in MANET Against Direct Node-toNode Transmission Using Location-Aware Transmission in Ubicomp. ACCN 2016

[17] M. Kaleem GALAMALI, Assoc. Prof Nawaz MOHAMUDALLY, Model of Overall Node Extra Energy Savings Achievable in MANET against Direct Node-toNode Transmission Using Location-Aware Transmission in Ubicomp. ACCN 2016

[18] M. Kaleem GALAMALI, Assoc. Prof Nawaz MOHAMUDALLY, Model of Energy Consumption Ratio Achievable in MANET Using Location-Aware Transmission in Ubicomp. ACCN 2016

[19] M. Kaleem GALAMALI, Assoc. Prof Nawaz MOHAMUDALLY, Model of Minimum Energy Consumption Ratio Achievable in MANET Using LocationAware Transmission in Ubicomp. ACCN 2016

[20] M. Kaleem GALAMALI, Assoc. Prof Nawaz MOHAMUDALLY, Model of Maximum Energy Consumption Ratio Achievable in MANET Using LocationAware Transmission in Ubicomp. ACCN 2016

[21] M. Kaleem GALAMALI, Assoc. Prof Nawaz
MOHAMUDALLY, Model of Overall Energy Consumption Fairness Ratio Achievable in MANET Using LocationAware Transmission in Ubicomp. ACCN 2016

[22] M. Kaleem GALAMALI, Assoc. Prof Nawaz MOHAMUDALLY, Model of Overall Energy Consumption Fairness Proportion Achievable in MANET Using LocationAware Transmission for Ubicomp, CEET 2016

[23] M. Kaleem GALAMALI, Assoc. Prof Nawaz MOHAMUDALLY, Model of Minimum Fairness Proportion Achievable in MANET Using Location-Aware Transmission for Ubicomp, CEET 2016

[24] M. Kaleem GALAMALI, Assoc. Prof Nawaz MOHAMUDALLY, Model of Maximum Fairness Proportion Achievable in MANET Using Location-Aware Transmission for Ubicomp, CEET 2016

[25] M. Kaleem GALAMALI, Assoc. Prof Nawaz MOHAMUDALLY, Model of Sender Fairness Proportion Achievable in MANET Using Location-Aware Transmission for Ubicomp, CEET 2016

[26] M. Kaleem GALAMALI, Assoc. Prof Nawaz MOHAMUDALLY, Model of Distance Travelled by packets in MANETs using Location-Aware Transmission for Ubicomp, CEET 2016

[27] M. Kaleem GALAMALI, Assoc. Prof Nawaz MOHAMUDALLY, Model of Maximum CBR Distance Travelled by packets in MANETs using Location-Aware Transmission for Ubicomp, CEET 2016

[28] M. Kaleem GALAMALI, Assoc. Prof Nawaz MOHAMUDALLY, Model of Minimum CBR Distance Travelled by packets in MANETs using Location-Aware Transmission for Ubicomp, CEET 2016

[29] M. Kaleem GALAMALI, Assoc. Prof Nawaz MOHAMUDALLY, Model of Range CBR Distance Experienced by Transmissions in MANETs using LocationAware Transmission for Ubicomp, CEET 2016

[30] M. Kaleem GALAMALI, Assoc. Prof Nawaz MOHAMUDALLY, Trend Analyses of Parameters of Equations for Sender Node Energy Savings Achievable in ubicomp MANETs using Location-Aware Transmission, ACCN 2017.

[31] M. Kaleem GALAMALI, Assoc. Prof Nawaz MOHAMUDALLY, Trend Analyses of Parameters of Equations for Overall Node Energy Savings Achievable in ubicomp MANETs using Location-Aware Transmission, ACCN 2017.

[32] M. Kaleem GALAMALI, Assoc. Prof Nawaz MOHAMUDALLY, Trend Analyses of Parameters of Equations for Sender Node Extra Energy Savings Achievable in MANET against Direct Node-to-Node Location-Aware Transmission, ACCN 2017.

[33] M. Kaleem GALAMALI, Assoc. Prof Nawaz MOHAMUDALLY, Trend Analyses of Parameters of Equations for Overall Nodes Extra Energy Savings Achievable in MANET against Direct Node-to-Node Location-Aware Transmission, ACCN 2017.

[34] M. Kaleem GALAMALI, Assoc. Prof Nawaz MOHAMUDALLY, Trend Analyses of Parameters of Equations for Energy Consumption Ratio Achievable in Ubicomp MANET Using Location-Aware Transmission, ACCN 2017.

[35] M. Kaleem GALAMALI, Assoc. Prof Nawaz MOHAMUDALLY, Trend Analyses of Parameters of Equations for Minimum Energy Consumption Ratio Achievable in Ubicomp MANETs Using Location-Aware Transmission, ACCN 2017.

[36] Markus Bylund and Zary Segall, Towards seamless mobility with personal servers, 2004.

[37] Masugi Inoue, Mikio Hasegawa, Nobuo Ryoki and Hiroyuki Morikawa, Context-Based Seamless Network and Application Control, 2004

[38] Xiang Song, Umakishore Ramachandran, MobiGo: A Middleware for Seamless Mobility, College of Computing Georgia Institute of Technology, Atlanta, GA, USA, August 2007

[39] Budzisz, Ferrús, R., Brunstrom A., Grinnemo, K, Fracchia R., Galante, G., and Casadevall, F. Towards transport-layer mobility: Evolution of SCTP multihoming, March 2008

[40] Paul Dourish \& Genevieve Bell, Divining a digital future, 
2011.

[41] Xiang Song, Seamless Mobility In Ubiquitous Computing Environments, PhD Thesis, Georgia Institute of Technology, August 2008

[42] Kevin O Mahony, Jian Liang, Kieran Delaney, User-Centric Personalization and Autonomous Reconfiguration Across Ubiquitous Computing Environments, NIMBUS Centre Cork Institute of Technology, Cork, Ireland, UBICOMM 2012

[43] Pablo Vidales, Seamless mobility in $4 \mathrm{G}$ systems, Technical Report, University of Cambridge, Computer Laboratory, Number 656, November 2005

[44] João Pedro Sousa and David Garlan, Aura: An Architectural Framework for User Mobility in Ubiquitous Computing Environments, School of Computer Science, Carnegie Mellon University, USA, August 2002

[45] Dennis Lupiana, Ciaran O’Driscoll, Fredrick Mtenzi, Defining Smart Space in the Context of Ubiquitous Computing, Dublin Institute of Technology, Ireland, Special Issue on ICIT 2009 Conference - Web and Agent Systems, 2009

[46] N.S.V.Shet1, Prof.K.Chandrasekaran2 and Prof. K.C.Shet3, WAP Based Seamless Roaming In Urban Environment with Wise Handoff Technique, International Journal of UbiComp (IJU), Vol.1, No.4, October 2010

[47] Yipeng Yu Dan He Weidong Hua Shijian Li Yu Qi Yueming Wang Gang Pan, FlyingBuddy2: A Braincontrolled Assistant for the Handicapped, Zhejiang University, UbiComp'12, September 5-8, 2012

[48] Jing Su, James Scott, Pan Hui, Jon Crowcroft, Eyal de Lara Christophe Diot, Ashvin Goel, Meng How Lim, and Eben Upton, Haggle: Seamless Networking for Mobile Applications, 2007

[49] Rui Han, Moustafa M. Ghanem, Li Guo, Yike Guo*, Michelle Osmond, Enabling cost-aware and adaptive elasticity of multi-tier cloud applications, Future Generation Computer Systems, 2012

[50] Byrav Ramamurthy, K. K. Ramakrishnan, Rakesh K. Sinha, Cost and Reliability Considerations in Designing the NextGeneration IP over WDM Backbone Networks, 2012.

[51] Bhavish Aggarwal, Aditya Akella, Ashok Anand, Athula Balachandran, Pushkar Chitnis, Chitra Muthukrishnan, Ram Ramjee and George Varghese, EndRE: An End-System Redundancy Elimination Service for Enterprises, NSDI 2010, San Jose, CA

[52] Ashok Anand, Vyas Sekar and Aditya Akella, SmartRE: An Architecture for Coordinated Network-wide Redundancy Elimination, SIGCOMM 2009, Barcelona, Spain

[53] John Breeden II, "Smart-phone battery life could double without better batteries", Nov 14, 2012

[54] Andy Boxall, "When will your phone battery last as long as your kindle", December 5, 2012

[55] Imielinski, T. and Navas, J.C. (1999). GPS-based geographic addressing, routing, and resource discovery. Comms. ACM, Vol. 42, No. 4, pp. 86-92.

[56] Hightower, J. and Borriello, G. (2001). Location Systems for Ubiquitous Computing. IEEE Computer, Vol. 34, No. 8, August, pp. 57-66.

[57] Harter, A., Hopper, A., Steggles, P., Ward, A. and Webster, P. (2002). The Anatomy of a Context-Aware Application. Wireless Networks, Vol. 8, No. 2-3, Mar-May, pp. 187-197.

[58] Hightower, J., Brumitt, B. and Borriello, G. (2002). The Location Stack: A Layered Model for Location in Ubiquitous Computing. Proceedings of the 4th IEEE Workshop on Mobile Computing Systems \& Applications (WMCSA 2002), Callicoon, NY, USA, June, pp. 22-28.

[59] Graumann, D., Lara, W., Hightower, J. and Borriello, G. (2003). Real-world implementation of the Location Stack: The Universal Location Framework. Proceedings of the 5th IEEE Workshop on Mobile Computing Systems \& Applications (WMCSA 2003), Monterey, CA, USA, October, pp. 122-128.

[60] Ko, Y., \& Vaidya, N. H. (2000). Location-aided routing (LAR) in mobile ad hoc networks. Wireless Networks, 6(4), 307-321.
[61] Liao, W.-H., Tseng, Y.-C., \& Sheu, J.-P. (2001). GRID: a fully location-aware routing protocol for mobile ad hoc networks. Telecommunication Systems, 18(1), 37-60.

[62] Kuhn, F., Wattenhofer, R., Zhang, Y., \& Zollinger, A. (2003). Geometric ad-hoc routing: of theory and practice. In Proceedings of the ACM (PODC'03) (pp. 63-72).

[63] Jiang, X., \& Camp, T. (2002). Review of geocasting protocols for a mobile ad hoc network. In Proceedings of the Grace Hopper Celebration (GHC).

[64] Ko, Y. \& Vaidya, N. H. (1999). Geocasting in mobile ad hoc networks: location-based multicast algorithms. In Proceedings of the IEEE (WMCSA'99) (pp. 101).

[65] Mauve, M., Fuler, H., Widmer, J., \& Lang, T. (2003). Position-based multicast routing for mobile ad-hoc networks (Technical Report TR-03-004). Department of Computer Science, University of Mannheim.

[66] Xu, Y., Heidemann, J., \& Estrin, D. (2001). Geographyinformed energy conservation for adhoc routing. In Proceedings of the ACM/IEEE (MOBICOM'01) (pp. 70-84).

[67] Hu, Y.-C., Perrig, A., \& Johnson, D. (2003). Packet leashes: a defense against wormhole attacks in wireless ad hoc networks. In Proceedings of the INFOCOM' 03 (pp. 19761986).

[68] Patwari, N., Hero III, A. O., Perkins, M., Correal, N. S., \& O’Dea, R. J. (2003). Relative location estimation in wireless sensor networks. IEEE Transactions on Signal Processing, 51(8), 2137-2148.

[69] Baldauf, M., Dustdar, S., \& Rosenberg, F. (2007). A Survey on Context Aware Systems. International Journal of Ad Hoc and Ubiquitous Computing, Inderscience Publishers. forthcoming. Pre-print from: http://www.vitalab.tuwien.ac.at/ florian/papers/ijahuc2007.pdf

[70] Hong, D., Chiu, D.K.W., \& Shen, V.Y. (2005). Requirements elicitation for the design of context-aware applications in a ubiquitous environment. In Proceedings of ICEC'05 (pp. 590-596).

[71] Neeraj Tantubay, Dinesh Ratan Gautam and Mukesh Kumar Dhariwal, A Review of Power Conservation in Wireless Mobile Ad hoc Network (MANET)", International Journal of computer Science Issues, Vol 8, Issue 4, No 1, July 2011

[72] Wenrui Zhao, Mostafa Ammar and Ellen Zegura, "A Message Ferrying Approach for Data Delivery in Sparse Mobile Ad Hoc Networks", MobiHoc'04, May 24-26, 2004, Roppongi, Japan.

About Author (s):

Associate Professor Nawaz Mohamudally works at University of Technology, Mauritius (UTM) and has undertaken supervision of MPhil/PhD Students for many years.

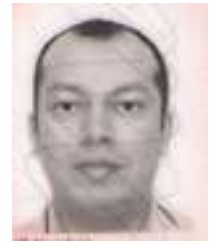

M. Kaleem Galamali is a part-time student (achieved M Phil Transfer on 28.10.2014, currently $\mathrm{PhD}$ student) at UTM under supervision of A.P. Nawaz Mohamudally. 